\title{
Improvement of Chemistry Learning Outcomes of Class XI Students High School Through Peer Tutors on Colloid Material
}

\author{
Wiwik Kastria Putri, Elferida Sormin*, Leony Sanga Lamsari Purba
}

Chemistry of Education, Universitas Kristen Indonesia, Cawang, Jakarta, Indonesia

elferidasormin@yahoo.com

\begin{abstract}
This research was conducted to find out whether there was an increase in student chemistry learning outcomes that were taught using the peer tutoring method, research was conducted on high school students in class XI with colloidal properties. This research is a quantitative study with statistical data processing using SPSS 21 for windows with paired $t$ test. The results showed that there were chemistry learning outcomes of class XI high school students who were taught using peer tutors, where based on the results of data analysis using paired t test it was found that the $t$ count of 13,010 was greater than $t$ table with the number of samples 29 at the significance level of 0.05 namely 2.045 , thus $t$ count is greater than $t$ table which means there is a significant increase in the chemistry learning outcomes of class XI high school students with an improvement category based on the results of $\mathrm{N}$ gain of $51 \%$ in the medium category.
\end{abstract}

\section{Keywords: Learning outcomes, Peer Tutors, Colloidal Material}

\section{INTRODUCTION}

Education is able to develop one's abilities to be better in dealing with the times. The ability referred to is the ability that is in accordance with Indonesian national education standards as stipulated in Government Regulation of the Republic of Indonesia No. 19 of 2005. National Education Standards must be a reference in achieving educational goals in Indonesia (BSNP, 2006). The quality of education in Indonesia is currently still low due to many factors including: low physical facilities, low quality of teachers, low teacher welfare, low student achievement, low educational equalization opportunities, low relevance of education to needs, and high costs of student education (Heri, 2015). This is further strengthened by student learning outcomes that are still relatively low. Specifically, if traced data about student chemistry learning outcomes in Indonesia in the 2016/2017 school year is to get results with an average value of $33.4 \%$ of the standard value of 5.5 (Puspendik, 2018).

Based on observations made through interviews with chemistry teachers at SMA Angkasa 2 Jakarta that chemistry learning outcomes are still low with the average value of UN Chemistry in 2016/2017 not reaching the standard of 5.5. At the time of the interview, according to the teacher's statement, during the learning process students were more active in moving physically, and were often sleepy during the learning process so that students lacked focus on learning which resulted in many student learning outcomes not yet reaching the KKM that had been set. Students consider learning chemistry to mean learning about reactions. One of the teacher's efforts to overcome many students who do not reach the minimum completeness criteria (KKM) is to hold a Remedial, but these efforts have not shown good results. But it is undeniable that in a class there are students who have more understanding than others, even though the percentage is very small, where students who have more ability, will more quickly accept and understand the subject matter. Conversely there are some students whose ability is lacking in understanding the lesson so that its development is a bit late.

Teacher observations among students actively communicate with each other but the topic of conversation is not related to the subject matter. In addition, teachers see a tendency for individual traits 
in student learning. Therefore it is necessary to make improvements and changes in the teaching and learning process, one of them through peer tutors (Burgess et al., 2014; Evans and Moore, 2013; Roscoe and Chi, 2007). A student is more likely to accept peer information, because in communication they can use their own language and there is no shame in asking (Galbraith and Winterbottom, 2011). The peer tutoring method is a method that involves students who have above average abilities to help other students understand the subject matter (Arjanggi and Suprihatin, 2010a). In the method of peer tutoring students who are assigned to become tutors learn a subject matter, but at the same time he will be assigned as a resource for other students. The strategy is a practical way to produce mutual teaching activities between peers in the classroom. Mutual respect and understanding are fostered among students who work together. Through this method active students are expected to help foster the interest of other students who tend to be passive, so that overall student learning achievement can increase (Ahdiyat, Maman, 2014; Arjanggi and Suprihatin, 2010b; Febianti, 2014; Lutvaidah, 2016). The peer tutoring method is guidance or assistance given to others of the same age. Learning together in groups with peer tutors is one of the characteristics of competency-based learning, through interacting and communicating activities, students become active learning, they become effective.

Colloid system is one of the contextual and rote material and the material that is related to our daily lives. With the use of peer tutoring methods in learning chemistry on colloidal material students are able to work and when they learn with peer tutors students also develop better abilities to listen, concentrate, and understand what is learned.

Some researchers previously through journals found that there was an increase in learning outcomes using the peer tutoring method. The results of the assessment of learning achievement cognitive and affective aspects also increased from cycle I to cycle II. In the first cycle of students' cognitive learning completeness was $68.75 \%$, while in the second cycle completeness achieved was $90.63 \%$, from the affective aspect, the percentage of students who were in the excellent and good category was $78.13 \%$ in the first cycle and increased to $84.37 \%$ in the second cycle (Sanubari et al., 2014). The average learning outcomes of Class II students experienced significant changes starting from the pre-cycle to the implementation of the second cycle (Adi Palistini, 2018; Rosidin, 2015). there was a significant increase in every meeting that occurred from $72 \%$ (good) in meeting 1 , to $88 \%$ (very good) in meeting 2 , and reached $92 \%$ (very good) in meeting 3 . Likewise research conducted by Mawah M (2015) states that the use of peer tutoring methods gives positive results (Indrianie, 2015).

Based on the problem formulation above, the purpose of this study is to find out the significant improvement in chemistry learning outcomes of Class XI high school ANGKASA 2 students using the peer tutoring method?

\section{METHOD}

\subsection{Population and Sample}

The population in this study were 60 students of class XI Angkasa 2, while the sample was students of class XI MIA 3 consisting of 30 students as experimental classes and students of class XI MIA 4 consisted of 30 students as control classes taken with the Purposive Sampling technique.

\subsection{Data collection technique}

From this study data obtained in the form of scores from student chemistry learning outcomes obtained through the provision of student chemistry learning outcomes tests in the discussion of the colloidal system (pretest and posttest). These consist of questions on the subject of the colloidal system. Fill out the questions with multiple choice questions as many as 30 questions with options a, b, c, d, e with cognitive aspects of questions $\mathrm{C} 1, \mathrm{C} 2, \mathrm{C} 3$, and $\mathrm{C} 4$ (Bloom, 1979; Bloom and Krathwohl, 1956).

\subsection{Research Instrument Validation Techniques}

The technically testing the validity of construction and content validity can be assisted by using the instrument lattice in the grid there are variables studied, indicators as benchmarks and item numbers (item) questions or statements that have been translated from the indicators (Sugiyono, 2015). The validity test in this research was carried out by consulting the supervisor about the instruments that had been prepared and asking for expert lecturers to be examined and evaluated systematically whether the items represented what they wanted to measure. 


\subsection{Assumption of Test}

\subsubsection{Normality Test}

Normality test is used to find out whether the research comes from a population that is normally distributed or not (Budiyono, 2004). The normality test uses the Kolmogorof Smirnov technique through SPSS 21 for windows because the number of study samples is $\leq$ 50 students. The distribution is said to be normal or cannot be seen in the SPSS test table of normality by looking at the significance level, the data will be said to be normal if the significant value is $\geq 0.05$

How to find out the significance or insignificance of the normality test results is by paying attention to the numbers in the significant column (sig). To determine data normality, the significance level of the test uses $\alpha=0.05$. If significant is obtained $>0.05$, then the sample comes from a normal distribution population. However, if it is significant $<0.05$, then the sample does not come from a normal distribution population.

\subsubsection{Homogeneity Test}

If the sample is normally distributed and homogeneous, then a parametric test is performed by testing statistics using a t test with a significant level of $\alpha=0.05$. This test is used to determine whether there is an average difference for more than two groups of samples that are not connected. If the difference is higher. After the student learning outcomes data meet the normal requirements then hypothesis testing is performed.

\subsection{Data Description}

The study presents the results of the analysis in the form of descriptive dependent variable data (Y) which can be presented histograms based on data frequency, which is equipped with data interpretation. The number of subtitles for the study of dependent variable (Y) data in each group is in accordance with the research design (Thoifah, 2015)

Hypothesis testing is done using SPSS 21 for windows with paired $t$ test with the provisions of a significant level (2-tailed) < probability 0.05 , and $t_{\text {table }}$ for 60 samples

$\mathrm{H}_{\mathrm{a}}$ is accepted if $\mathrm{t}$ count $>\mathrm{t}$ table

$\mathrm{H}_{0}$ is accepted if $\mathrm{t}$ count $<\mathrm{t}$ table

\section{RESULT AND DISCUSSION}

\subsection{Hypothesis Test Results}

After obtaining the prerequisite test results for data analysis, it can be stated that the two data are normally distributed and homogeneous. Therefore, the next step to do is test the hypothesis.

Hypothesis testing used parametric statistical test independent sample $t$ test with test criteria, if the value of Sig (2-tailed)> probability 0.05 , then there is no difference or Ho is accepted and if Sig (2-tailed) <probability 0.05 then there is a difference or $\mathrm{Ha}$ is accepted. Hypothesis testing is used to find out the increase in student chemistry learning outcomes using the Peer Tutor learning method.

From the results of the SPSS analysis it is found that $t$ count 13,010 is greater than $t$ table 2,045, thus there is an increase in chemistry learning outcomes of class XI high school students who are taught using peer tutoring methods

This research was applied in Angkasa 2 High School in class XI with colloidal material, so that the study population was class XI MIA, amounting to two classes as many as 74 people and each class as many as 30 during the study. For sampling based on purposive sampling technique that is deliberate sampling as desired with the required sample requirements. Furthermore, researchers conducted an analysis of the pretest and posttest in the experimental and control classes that have been obtained from research and data collection activities. Before the researcher took the data, the question instruments were firstly validated by expert validators (lecturers) to find out the level of difficulty of the questions to be tested with 30 valid questions, and only 20 questions were tested because some $\mathrm{C} 1$ and $\mathrm{C} 2$ questions were too many, so the correction results from the lecturer become a consideration for not testing other questions. Before being tested based on an analysis of the initial conditions of the population, namely through the analysis of student pretest data the results were obtained that the population had the same homogeneity and the normality test results of the experimental class with sig values. 0,200, control class with sig. .200. All normality test results using the Kolmogorov-Smirnov formula above an alpha value of 0.05 means that all data are normally distributed. After obtaining a value in the experimental and control group for sampling based on the porposive sampling technique, namely deliberate sampling.

Based on the porposive sampling technique the researcher determines the class intentionally, the 
experimental class that gets learning using the peer tutoring method and the control class gets conventional learning. The research data is then processed using statistical tests. From the results of data processing it can be seen in the experimental class the lowest pretest score is 25 and the highest score is 60 with an average of 41.3 . While the lowest post test score was 55 and the highest was 85 with an average of 72.6. All students who were used as experimental samples did not complete or did not reach KKM because they did not understand the material, did not understand it and were not treated, it meant that students learned colloidal material. According to Skinner learning is a behavior. When people learn, the response is better on the contrary if students do not learn, the response decreases. While in the experimental class posttest students completed or reached $\geq 75$ because they were given treatment and control class pretest score 15 and the highest score 60 with an average of 40.3 while the lowest posttest score was 35 and the highest 80 with an average of 67. All students sampled classes incomplete control because students do not understand the material. Whereas in the posttest the control class students had completely reached KKM $\geq 75$.

To find out whether student learning outcomes increase or not do a test. The results of the gain test in both classes amounted to 0.51 with the second category included in the medium category. The learning process in the experimental class gets learning activities using the peer tutoring method. The research activities were carried out in three stages. In the first stage, which is the preparation stage, the researcher determines the subject and several students who become tutors, then the researcher exercises the tutor before the tutor teaches in class. In the second stage, namely the implementation stage where the researcher first gives an explanation and divides the group, each group there is one tutor. During the learning process, several questions arise from students, but these questions can be answered by the tutor. At the last stage is the evaluation stage. The researcher gave several oral and written questions. When the teacher gives oral questions. Only a few students can answer.

In the control class applied conventional methods namely lectures and questions and answers. The learning process in the control class lasted for 2 days for 4 hours meeting. During the learning process using the lecture method many researchers take roles and students only listen to the explanation from the teacher. From the results of the control class it was found that only a few students who had an interest and were enthusiastic about learning. While the student experiment class looks enthusiastic and shows interest in following the lesson. Many things can be done when conducting research using the peer tutor method, one of which is the constraints in carrying out learning, which is required more time in using the peer tutoring method.

From the results of research and observations that have been made, using the peer tutoring method is very helpful in learning and attracts the attention of students, in addition it can build solidarity from each student. The use of peer tutoring method when seen from the significant value (2-tailed) <probability 0.05 , and the results of the test gain in the class

The results of the isolation in the form of white crystals which have a melting point of 121.2-123 oC with IR spectroscopy test gives a peaking peak at a wavelength of 3100-2700 cm-1 (strong peak), 1700$1690 \mathrm{~cm}-1$ (medium peak), 1650-1520 cm-1 (weak peak), $1275 \mathrm{~cm}-1$ (medium peak and $882.6-715 \mathrm{~cm}-1$ (medium strong peak)

\section{CONCLUSSION}

Based on the results and discussion which can conclude that by using Peer Tutors there is a significant increase in chemistry learning outcomes in class XI students, especially in colloidal material with.

\section{ACKNOWLEDGMENTS}

Thank you to all parties who have supported the implementation of this research, specifically for SMA 2 Angkasa East Jakarta and the Chemical Education Study Program at the Christian University of Indonesia.

\section{REFERENCES}

Adi Palistini, N.L., 2018. Penerapan Metode Tutor Sebaya Untuk Meningkatkan Hasil Belajar Pendidikan Agama Hindu Pada Siswa Kelas III Sekolah Dasar Negeri 1 Sukadana. J. Penjaminan Mutu. https://doi.org/10.25078/jpm.v4i1.402

Ahdiyat, Maman, S., 2014. Metode Tutor Sebaya Untuk Meningkatkan Hasil. Formatif.

Arjanggi, R., Suprihatin, T., 2010a. METODE PEMBELAJARAN TUTOR TEMAN SEBAYA MENINGKATKAN HASIL BELAJAR BERDASAR REGULASI-DIRI. Makara Hum. 
Behav.

Stud.

Asia.

https://doi.org/10.7454/mssh.v14i2.666

Arjanggi, R., Suprihatin, T., 2010b. Metode pembelajaran teman sebaya. Makara. Sos. Hum.

Bloom, B.S., 1979. Taxonomy of Educational Objectives.

Bloom, B.S., Krathwohl, D.R., 1956. Taxonomy of Educational Objectives: The Classification of Educational Goals, in: Handbook I: Cognitive Domain.

BSNP, 2006. Peraturan Mentri Pendidikan Nasional Republik Indonesia No 22 Tahun 2006 Tentang Standar Isi Untuk Satuan Dasar dan Menengah.

Budiyono, 2004. Statistika Untuk Penelitian. UNS Press, Solo.

Burgess, A., McGregor, D., Mellis, C., 2014. Medical students as peer tutors: A systematic review. BMC Med. Educ. https://doi.org/10.1186/1472-6920-14115

Evans, M.J., Moore, J.S., 2013. Peer tutoring with the aid of the Internet. Br. J. Educ. Technol. https://doi.org/10.1111/j.1467-8535.2011.01280.x

Febianti, Y.N., 2014. Peer Teaching (Tutor Sebaya) Sebagai Metode Pembelajaran Untuk Melatih Siswa Mengajar. Edunomic J. Ilm. Pendidik. Ekon.

Galbraith, J., Winterbottom, M., 2011. Peer-tutoring: What's in it for the tutor? Educ. Stud. https://doi.org/10.1080/03055698.2010.506330

Indrianie, N.S., 2015. Penerapan Model Tutor Sebaya pada Mata Pelajaran Bahasa Inggris Reported Speech terhadap Hasil Belajar Peserta didik MAN Kota Probolinggo. J. Kebijak. dan Pengemb. Pendidik.

Lutvaidah, U., 2016. Keefektifan Strategi Pembelajaran antara Metode Tutor Sebaya dengan Metode Tanya Jawab dalam Pengajaran Remidial Materi Fungsi Limit. Form. J. Ilm. Pendidik. MIPA. https://doi.org/10.30998/formatif.v6i3.998

Puspendik, 2018. Score Achievements of National Examination 2017/2018 Akademic Year. Jakarta.

Roscoe, R.D., Chi, M.T.H., 2007. Understanding tutor learning: Knowledge-building and knowledgetelling in peer tutors' explanations and questions. Rev. $\quad$ Educ. Res. https://doi.org/10.3102/0034654307309920

Rosidin, M., 2015. METODE TUTOR SEBAYA DALAM KERJA KELOMPOK DAPAT MENINGKATKAN MINAT DAN PRESTASI BELAJAR PEMAHAMAN STATISTIKA. Eduma Math. Educ. Learn. Teach. https://doi.org/10.24235/eduma.v4i1.14

Sanubari, F., Yamtinah, S., Redjeki, T., 2014. Penerapan Metode Pembelajaran Tutor Teman Sebaya Dilengkapi Dengan Media Interaktif Flash Untuk Meningkatkan Minat Dan Prestasi Belajar Siswa Kelas Xi Ipa 1 SMA Negeri 1 Sukoharjo Tahun Pelajaran 2013 / 2014 Pada Materi Larutan Penyangga. J. Pendidik. Kim. 3, 145-154.

Sugiyono, 2015. Metode Penelitian Pendidikan: Pendekatan Kuantitatif, Kualitatif, dan RND. Alfabeta, Bandung. 